\title{
Judges According To Islamic Law and Indonesian Law In Islamic Court
}

\author{
Hj. Jamillah,SH, MH \\ Kopertis Dpk Wil-1, Faculty of Law, Medan Area University (UMA), Medan, Indonesia
}

\begin{abstract}
A judge is an important element in implementing Islamic Shari'ah. The judge is a person who takes a responsibility for maintaining and sustaining the laws 'in order to uphold truth and justice. Therefore, Islam gives a strict requirement for someone who wants to be appointed as judges. The goal is to make sure the person holding the position of judge is really the authoritative, extensive knowledge, and trustworthy. In the process of removal of judges, there are three possible successors are chosen by Imam. First, a judge is not better than the first judge. Second, replacement of judges at least have the same quality. Third, the replacement judge has better quality of his integrity. Ijtihad judge reflected through its decisions in resolving a problem that there is no basis in the Qur'an and Sunnah. Thus the results of ijtihad judge is a legal basis in determining the verdict of a case. These decisions would not be final. That is, the verdict or ijtihad judge results could still be revisited when the verdict is violated with its nash.
\end{abstract}

Keywords: Judges; Islamic Law; Indonesian Law; Islamic Court; Imam

\section{INTRODUCTION}

Justice at Prophet era is the most important phase in the history of Islamic court. At the time, Prophet is an authority holder of jurisdiction even though he ever delegates the tasks some of his companions on a limited basis. At that time, the judiciary is an integral part of establishing government authority in general ('ammah region). The development of judicial system brought by the Prophet Muhammad, is much more advanced than justice in Jahiliyah era. The sources of law as a key reference for jurisdictional authorities are revelations-both in the form of Qur'an and Sunnah SAW-and ijtihad. Justice at the time of Prophet and performed by Prophet himself is a direct translation of the verses and sunnah qawliyah of Prophet implemented in ideal practice.

The judicial process in the era of Prophet Muhammad SAW is very simple and straightforward, and it concerns with the substance than procession. The current judicial system also provides a starting point and basic principles for the development of the judicial system that develops in Islamic civilization which includes in strengthening the new institutions such as hisbah and judiciary madzälim. A judge is an important element in implementing Islamic Shari'ah. The judge is a person who takes a responsibility for maintaining and sustaining the laws 'in order to uphold truth and justice. Therefore, Islam gives a strict requirement for someone who wants to be appointed as judges. The goal is to make sure the person holding the position of judge is really the authoritative, extensive knowledge, and trustworthy. If the goal does not met because the terms that have been violated, the judge could have been dismissed. The government has the right to dismiss the judge that he adopted when there is a strict reason. When someone has been appointed as a judge, he would have the authority according to the level of judicial and in case he should do ijtihad if he is a judge who has reached the level of mujtahid judge.

\section{METHODOLOGY}

Fuqaha has determined the requirements to be a judge. Most of the requirements are agreed by them and some are rejected by them. The requirements that they agreed are baligh and sensible, independent, Muslim, can hear, see and speak, knows syariah laws. While the requirements disputed by them are al-adalah (credibility) and mujtahid. Generally, the requirements to be a judge can be summarized as follows:

a. Male

Whether or not a woman be a judge, it is still rising different opinion in figh scholars. It is not in spite of different understanding of hadith narrated by Imam Bukhari. There are scholars who argue that women can be as a judge but their authority is not absolute. Some scholars also said that a woman can be a judge for special cases allowed and not allowed for special cases too.

According to Imam Malik, Imam Shafi, Imam Hambali, women should not be served as a judge. The basis of their opinion are Q.S. An Nisaa ': verses 34, and Hadist of Rasululullah saying "that is not going to be happy a 
people who gave their concern to women" (HR. Bukhari). Hadith, which states that women's intellectual are less than the intellectual of men" (HR. Ibn Majah). Other opinions that support to denial women to be an absolute qadi (yudicative) because according to syara, this job needs a complete thinking while in general women have a weak thinking. in which Prophet interprets about the un-complete mind of women where the testimony of women is half compared by men.

Abu Said Al-Hasan ibn Abi Hasan Yasar Al Basri, Ibn Jarir At-Tabari and Az Zahiri inform that women can be as an absolute judge in all cases. The reason that women have a potential and may be served as a judge. Another reason is based on the principle that every person is able to mediate among human beings, so the legitimate decision is a woman can be as a judge unless things which are specialized by ijma ', that is a problem of great leadership (al- Imamah al- Kubra)

\section{b. Having Mind}

This provision is agreed and it is not only enough to be mukallaf, because he must be completely healthy in mind, smart, and can solve the thorny problem with his intelligence. Moslem judge has a different opinion regarding to an illiterate to be a judge, though he has an ability in understanding syara' laws'. In this issue there are two opinions, some jurists say that an illiterate can be as a judge. It is based on the reason that Prophet Muhammad illiterate, but he is a reliable lawyer. While the second opinion said that the appointment of judges from those who are illiterate are not valid, even though he has an ability in the field of Islamic law. But there are some schools in Shafi'i who said that appointing judges from those who are illiterate are allowed as long as the person has expertise in Islamic law.

\section{c. Islam}

Moslem is one of the requirements whether someone can be as a judge or not, because Allah says "And Allah is not going to make way for the infidels over the believers".

So it is forbidden for non-Moslem be as an absolute judge. Moslem jurists among Hanafi confirms that the appointment of non-Muslim judges to resolve cases occurred between Muslims with people who are not Muslim. It is as stated by Ibn Abidin that allowed induct special judge for dhimma groups to resolve cases among them. For the jurists among Hanafi, the argument that requires appointing non-Muslims as a judge of Islam based on the principle that the people are not Muslims worthy of being witness to their neighbors, they also deserve to be judges of their fellow.

\section{d. Fair}

Fair means here is correct in conversation, trustworthy, guard of honor of all that is prohibited, honest when anger or in difficulties, and it is forbidden to appoint fasiq judge. And there are opinion saying, we can appoint fasiq judge, and it is supported in a strong opinion of Hanafi, that fasiq judge's decision is valid as long as the decision is not contrary to the law and the laws applied, although there are others more worthy to occupy this position. Therefore, al-Kasani said that fair is not a requirement allow or not allow someone appointed to be a judge. So it allowed to appoint judge who is fasiq and his decision is legitimate as long as it is not beyond the religion law. In this globalization era, it seems very difficult to get someone who really fair, as required by the syara' laws to be appointed as judges. In this case, Abdul 'Autwah argues that this situation should not be a reason to remove a judge from the famous wicked, but let appointing judges of the person most worthy among existing and prioritize the most excellent among those who are less worthy. In this regard, the majority of Muslim jurists warned that this requirement is very important to be implemented as a private good, noble spirit, faith, and the authority of a judge will reassure the public about the judicial institution.

\section{e. Knowledgeable}

The jurists among Shafi'i, Hanbali, and partly among Hanafi mahzab require the appointment of judges should be knowledgeable in the field of Islamic law and his cleverness should be having mujtahid standard. In connection with this, it is not legitimate to appoint judges from ignorant and mukalid. This rajih opinion, according to Hanafi, may be appointed as a judge of a follower of one of the madzhab, and also in the history of Imam Malik, and according to ad-Dasuki, it is more legitimate.

Nowadays it is difficult to find out qualified persons to the level of absolute mujtahid. Looking for people who have knowledge at the level of mujtahid, muqayyad, or mass mujtahid are also too difficult. In this case, alSharbaini argues that if the person who has knowledge to the extent of mujtahid is hard to come by, the post of judges should not be empty, but still required.

\section{f. Perfect in Five Senses}

The person who will be appointed as a judge should have perfect senses, especially hearing and not mute. It is important for a judge because he will provide direction and asks all particulars to the parties litigant. 
Muslim jurists among Shafi'i madhhab state that within the meaning of blind is someone's eyes is blurred, only look a shadow and cannot recognize the right thing. If someone only suffers from the disease far or nearsightedness and farsightedness of night and day, the judge may make punishment when he saw it. If he is punished in a state he did not see, the decision handed down is not valid, because it is characterized in a state of blind.

But according to al-Azra'I, the appointment of judge as these circumstances are invalid, this judge's decision is cancelled. While the appointment of judges whose blind eyes is only one, his decision is valid because he could see with one more eye.. Imam Malik and some legal experts among Shafi'i madhhab allow a blind person as a judge, it is based on the actions of the Prophet. which raises Ummu Maktum (the blind man) becoming governor in Medina. Imam Malik's opinion is rejected by scholarly saying that Ibn Ummu Maktum is appointed by the Prophet just becoming a pray imam and government affairs, never appointed as a judge. Thus, the appointment of judges should not be of blind and deaf. Meanwhile, another disability like maimed hand and leg stump can be appointed as a judge.

\section{g. Not a slave (independent)}

Experts in the various schools of Islamic law agree that the appointment of judges is not allowed from the absolute slaves. It is because a slave is considered not afford to have the ability by himself. Also because of its status as a slave, then he cannot give evidence in various cases, therefore, he cannot serve as a judge. If he is free, he may be appointed as a judge, even though he still bore wala '(the relationship with the former master). Therefore, today the world has agreed to abolish all forms of slavery, the terms "freedom" is in himself already met.

\subsection{The Appointment and Dismissal of Judges}

It is a requirement that every society requires the authorities to curb (association among) them their own affairs, and maintain welfare-benefit them, whereas general government authorities may not be able to handle its own entire affair society. It is definitely necessary to conduct human affairs, and carry the burdens of government, each of which is specifically implement their own fields, some of which are field qadla (judicial). Then of course the necessary officials will handle and also required the appointment, because it is a judge obliged to, and does not distinguish between the granting authority to judge by the authorities, or by way of delegation of authority to the servants of government for specific tasks in the field of justice, and on this basis, it is actually a judge leaned legal decision on appointment of the authorities.

The appointment of judges allowed by governmental authorities is fair or fraudulent. They might decide the case correctly, and authorities do not come to interfere with the judiciary. It turns out that the authorities do not intervene. In al-Fatawa al-Hindiyah, " it is allowed to appoint judges by a fair government authority as long as the judge has done a right allow. In any case, the fact that the judge should be appointed by the government authorities or his representative, then a judge shall not appoint himself and should not also appoint any other person to be a judge, for surely if the entire population of the country gathered and then choose someone to be appointed as judge it is not that person be the judge.

In an Islamic government, a head of state, caliph, or king has the right to appoint and dismiss a judge or chief justice based on personal considerations. This dismissal is done if the judge is considered less credible or indicated to make a fatal mistake. Because if the judge continues to be maintained, then it will arise mafsadah in the future. In addition, it will reduce the credibility of the government. According to Shafi'i madhhab, the government has the right to fire the judge when there is a cause that is willing, and not justified action dismissal without cause because it has a relation to the benefit of Muslims and the right people, then it is not justified dismissal action against judges not guilty, because it is equated with wakalah (representative) if you have to do with the rights of others.

In the replacement process, there are three possible replacements selected:

a. The substitute judges are no better than the first judge. It is definitely not allowed. It is the right of people to get a better service than the first judge which has been reduced even possibly eliminated by the arbitrariness of Imam.

b. Switching to a judge of the same quality. It is still debatable about skill. According to some scholars, such reimbursement can be justified. Because the concept of jurisprudence, if there is something equally good, then the Imam allows to choose one of them, including replacing a judge to another judge who has the equivalent quality. The same thing applies at the time of appointment (not replacement), when there are two (or more) that have equivalent quality. Another opinion stated, the action is not justified, because it will cause grief or anger sacked judges, because he felt his dismissal without good reason unfounded. The first judge disappointment this will eventually become a scourge dangerous, both for the government bureaucracy and security stability. Therefore, this will result in judges sacked retaliated. In contrast, if the 
decision is done during the period of appointment (not replacement). This burden is felt will influence significantly.

c. Replacing a judge who has a good integrity. It's obviously allowed. Because Imam has been putting more useful for the people. According to one opinion, the actions allowed dismissal without fault, because there is a history, that Ali bin Abu Talib never raises Abul Aswad (as a judge) then he fire him. Abul Aswad then asked, "Why did you just fire me, even though I'm not a traitor and no action mistake?". Ali replied, "I see you speak with high words of the parties litigant. And because the ruler has the right to fire officials, the subordinates also includes judges ". And act of dismissal since he (sacked) know about her dismissal. Abu Yusuf said, "Actually, since the enactment of the sacking of his successor has been appointed in order to maintain the rights of man". Likewise, the judge should resign, and act resignation since he left his job. In the opinion of jumhur, that the judges who resigned is not interrupted the continuity of his duties until the appointment of new officials, because in this case no one can cancel a right, and according to one opinion, it has not been apart so long as his resignation not yet known to lift it, and if it is figured with the opinion of Abu Yusuf, then in fact he had not detached until he received a termination letter, and this is in accordance with what goes on today. And on that basis, then during the dismissal letter is not delivered, then all decisions are still valid as well as all the decision can still be implemented during the official resignation accepted. And if a judge dies or fired by an unauthorized fire him, then a new appointment is not required, because basically he is carrying out public authority in the field of justice from the people and prosecute on its behalf.

\subsection{The Competence of Judges}

According to fiqih ulema, after laws of jurisprudence is completed recorded in the reign of Bani Abbas, the judiciary and the authority of judges is distinguished by their territories as follows:

\section{a. Qadi al-Qudat}

This term is used to refer judicial office based on the center of dynastic rule of Bani Abbas in Baghdad. This position is first established during the reign of Caliph Harun ar-Rashid, and the first man that he believes to hold this position is Abu Yusuf, is one of Abu Hanifa's students. Qadi al-Qudat has the authority to submit proposals and special consideration on the appointment to the deputy regarding to the appointment of judges in the areas of power. In addition, he also occupies the same position with the wazir (minister). In the reign of Fatimiah Dynasty in Egypt (909-1171), the position of Qadi al-Qudat is higher than vizier. Then when the Islamic areas started to break away from the Abbasid Dynasty in Baghdad, they appoint judges as qadi alqudat. While in Cordova, magistracy which has the same authority with Qadi al-Qudat is Qadi al-jama'ah, as it is ever given to Ibn Ruyd, a figure of Maliki mazhab.

\section{b. Qadi al-Wilayah}

Qadi al-Wilayah is known at Mamluk Dynasty in Egypt (1250-1517) and this term is used to refer to the position of judge whose authority is limited to certain areas. Qadi al-Wilayah is appointed by the caliph on the proposal and consideration given by Qadi al-qudat. Among the judges which are ever appointed as a Qadi al-Wilayah are Syahnun al-Maliki, a judge for the area of Morocco and Izzuddin bin Abdus Salam, a judge for Mesir.

\section{c. Qadi al-Askar}

This term is begun to be used during the reign of Sultan Yusuf Salahuddin al-Ayubi (532 H/ 1138 M-589 H/1193 AD) from Ayyubiah Dynasty. The duty is to prosecute violation committed by soldiers.

\section{d. Qadi al-Masjid}

It is in Basra and the function of judge is to resolve minor penalties for a maximum of 200 dirhams and also the determination of living. Judges perform their duties in an office located in Majid, 'Basra.

In the book al-Fiqh al-Islami wa 'Adillatuhu stated, "The authority of judge is distinguished by time, place, type of case and subject matter.

1. The authority based on time.

The judge is only authorized to investigate and prosecute the cases on a day or only at a certain period

2. The authority based on place

A judge only has the authority to investigate and adjudicate a case in one place.

3. The authority based on the type of case:

A judge is appointed to investigate and adjudicate some types of cases

4. Authority based on topic matter: 
The judge only has the authority to resolve cases in certain topics or issues such as the issue of endowments and legacy.

\section{DISCUSSION}

\subsection{Status of Ijtihad Judges}

Ijtihad according to Fuqaha term and experts in Usul is: "Devoting effort to infer the laws of the basics, with research that can deliver to that goal." Ijtihad here is in conjunction with the judiciary, absolutized to the path followed by the judges in their decisions, both with regard to the provisions of law or by way of concluding of the law that must be applied when the absence of the texts, although this very narrow field for countries that have laws

According to his nature, ijtihad is not in the same form, because of differences in the 'streets', then the difference in fiqh. It is evidence that must be for disagreement still there, and the differences arising from the results of ijtihad is a natural thing occurred among the judges applying the laws established in the articles is limited. Because most of them are at odds on the understanding, interpretation, and application of these chapters partly because it is unclear which specific instructions to the law so that it is a field for ijtihad. If the judge seek legal case that there is no provision of law, then he arrived at an opinion on the legal position, and then again the opinion before the verdict, in that case, he must decide on the basis of the opinion that is new, and it should not be decide on the basis of the first opinion. Because with a new opinion that means the first opinion has been canceled. As if the advent of the opinion that new after adjudication, then to decide the case of other similar he could only take his opinion first, and in this case Umar bin Khattab once said, "That's the decision we drop (in the past) and this our decision today that we drop ". If the judge has pronounced its verdict on the case, and then after there was a desire to revisit the decision he had dropped and canceled, then if the decision was indeed there is an error, which was not disputed by the jurists, it may be canceled, provided that the charges were true and provable and its witnesses is fair according to the birth, this is to maintain the dignity of the judge's decision."

\subsection{Religious Courts in Indonesia}

Religious court is an official designation (titelateur) for one of the four environments Justice State or Justice authority which is valid in Indonesia. Three other State Judicial environment are general courts, military courts and administrative courts. Religious courts is one of the three special courts in Indonesia. Two other special courts are military justice and administrative courts. It said special court for religious courts because it is handle specific case or about a particular class of people. In this case, the religious court is only authorized in certain areas of civil, not criminal, and also just for the people of Islam in Indonesia, in a case of certain Islamic civil, do not cover the entire civil of Islam. Religious court is the judicial Islam in Indonesia, because the types of cases that he should put him on trial, all of which are types of cases according to Islam. It is associated by the words "Islamic Justice" with the words "in Indonesia" because type of cases should be prosecuted which is the case does not cover all sorts of justice according to Islam universally. Strictly speaking, Islamic Courts is religious courts which are limiting adjusted with the state of Indonesia. Here we will talk about the terms of judges of religious courts in Indonesia as well as the appointment and dismissal.

\subsection{Requirements to be a judge in Islamic Court}

A judge is a key element in the trial. In fact, he is "identical" to the court itself. Freedom of judicial power is often identified with the freedom of judges. Similarly, the decision of the court identified with the judge's decision. Therefore, the achievement of law enforcement and justice lies in the ability and wisdom of the judge in formulating decisions that reflect fairness. In this regard, it appears idealization and presciption about judges. Among jurists, there are diverse views on the requirements to be appointed as a judge, including those regarding the ability of ijtihad. The other thing that became a talking point among them is gender. Men are the terms agreed to be appointed as judges. As for women, there are various views. In Indonesia, the idealization of justice is reflected in symbols kartika (taqwa), cakra (fair), candra (dignified), sari (virtuous), and tirta (honest). These abstract characteristics are required to be realized in the form of a concrete attitude of the judge, either in the workplace or outside the office. It is a criterion in assessing the conduct of judges.

The attitude in the workplace includes:

a. The attitude of the judge in a court

b. The attitude of judge with his peer

c. The attitude of judge with his staff

d. The attitude of judge with his leader

e. The attitude of the leadership towards his subordinates or colleagues and

f. Judge attitude towards other agencies. 
The properties are transformed into abstract judges requirements as stipulated in the legislation. He is transformed into Law No. 14 of 1985, Law No. 2 of 1986, Law No. 5 of 1986, Law No. 7 of 1989. It becomes a requirement of judges in all courts. According to the provisions of article 13 paragraph (1) of Law No. 7 of 1989, to be appointed as a judge on the Religious Court, a candidate must meet the following requirements:

a. Indonesia citizenship

b. Islam

c. Fear of God Almighty

d. Loyal to Pancasila and the Constitution of 1945

e. Not a former member of the banned Indonesian Communist Party organization, including its mass organizations or not someone involved directly or indirectly in the "Movement Counter-revolution G. 30. S / PKI", or forbidden another organization

f. Government officer

g. Bachelor of Sharia or law degree to master the law Islam

h. Aged at least 25 (twenty-five)

i. Authoritative, honest, fair, and behave beyond reproach.

The nine requirements that shows a mixture of product thinking jurists with the provisions applicable in general to judge at first instance. In general terms the judges at all judicial bodies are the same. It is seen in seven of the nine conditions, which must also be met by candidates for judge at the state court and state administrative court.

While the second and seventh terms apply only to prospective judges on the court within the religious courts, which are closely related to the product of thought jurists. It is consistent with the specificity of the judiciary in Indonesia, with jurisdiction over certain civil cases according to Islamic law among people who are Muslims. All the requirements be a judge are a unity that is cumulative. However, there are conditions that are concrete and there are conditions that are abstract. The terms that are concrete, namely citizenship, the religion, not a former member of forbidden organization, civil servants, fields of scholarship, and age. He can be known or proven by a written statement issued by the authorities. While certain other conditions are abstract, which is difficult to be known and measured simply. However, it is a requirement that is attached to each judge, so the judge that ideal figure is determined by the terms of the abstract. In this regard, the abstract search of the requirements that requires a specific approach in a more complex and specific.

\subsection{Appointment and Dismissal of Judges}

Law Act No. 71989 about Religious Courts states that judges are appointed and dismissed by President as Head of State on the proposal of the Minister of Religious Affairs under the approval of the Chairman of the Supreme Court (article 15, paragraph 1). The judge honorably discharged from his position because of the following reasons:
a. Personal request.
b. Physical or mental illness continously.
c. After the age of 60 (sixty) years
d. He is not proficient in his duties (Article 18).

Judge dishonorably dismissed from office:

a. If they are convicted of a criminal act

b. Misconduct

c. Continously doing malpractice in performing their duties.

d. Violating the oath of office.

e. Violates the prohibition referred to in Article 17.

A judge also could be suspended if there is an arrest warrant against him (the judge) and detention, and if the judges are required in advance of court in a criminal case without being held within the meaning of Article 1, paragraph 4 of Law No. 8 of 1981 on Criminal Proceedings.

\section{CONCLUSION}

From the above explanation, it can be concluded as follows:

1. Fuqaha has determined the conditions for judges, most of the requirements that they have agreed and other are differ. The terms that they agreed on is baligh and sensible, independent, Muslim, can hear, see and speak, knows syariah laws. As for the terms that are disputed by scholars is al-adalah (individual credibility) and mujtahid.

2. In the Islamic system of government, a head of state, the caliphate, or the king has the right to appoint and dismiss a judge or chief justice based on personal consideration. 
3. In the system of Indonesia Government, judges are appointed and dismissed by president as head of state on the proposal of the Minister of Religious Affairs under the approval of the Chief Justice of Agung.

4. In the process of removal of judges, there are three possible successors are chosen by Imam. First, a judge is not better than the first judge. Second, replacement of judges at least have the same quality. Third, the replacement judge has better quality of his integrity.

5. Ijtihad judge reflected through its decisions in resolving a problem that there is no basis in the Qur'an and Sunnah. Thus the results of ijtihad judge is a legal basis in determining the verdict of a case. These decisions would not be final. That is, the verdict or the ijtihad judge results could still be revisited when the verdict is violated with its nash.

\section{REFERENCES}

[1]. Bisri, Cik Hasan, Peradilan Agama di Indonesia, edisi revisi, Jakarta: PT. RajaGrafindo Perasada, cet. 4, 2003.

[2]. Bahnasawi, Salim Ali, Wawasan Sistem Politik Islam, Jakarta: Pustaka Al Kautsar, 1996.

[3]. Dahlan, Addul Aziz et al., Ensiklopedi Hukum Islam, Jakarta: PT. Ichtiar Baru van Hoeve, 2003, Jilid 3.

[4]. Haq, Abdul, Formulasi Nalar Fiqh, Telaah Kaidah Fiqh Konseptual, Surabaya: Khalista dan Kaki Lima, 2006.

[5]. Koto, Alaiddin, et.al, Sejarah Peradilan Islam, Jakarta: PT. RajaGrafindo Persada, 2011.

[6]. Madkur, Muhammad Salam, al-Qadhau fil Islam, terj. Imron AM., Peradilan Dalam Islam, (Surabaya: PT. BINA ILMU, t.thn.

[7]. Manan, Abdul, Etika Hakim Dalam Penyelenggaraan Peradilan, Suatu kajian Dalam Sistem Peradilan Islam, (Jakarta: Prenada Media Group, 2007.

[8]. Al-Mawardi, al-Ahkam as-Sulthaniah wa al-Wilayat ad-Diniah, tt: Dar al-Fikri, 1960.

[9]. Rusyd, Ibnu, Bidayatul Mujtahid, terj, Imam Ghazali Said, Bidayatul Mujtahid, Analisa Fiqih Para Mujtahid, (Jakarta: Pustaka Amani, 2007.

[10]. Rasyid, Roihan A., Hukum Acara Peradilan Agama Edisi Baru, Jakarta: RajaGrafindo, cet. 6, 1998.

[11]. Supriyadi, Dedi, Perbandingan Mazhab dengan Pendekatan Baru, Bandung, Pustaka Setia, 2008.

[12]. Undang-Undang Peradilan Agama (UU No. 7 Tahun 1989), Jakarta: Sinar Grafika, 1996.

[13]. Az-Zuhaili, Wahbah, Fiqh al-Islami wa Adillatuhu, Syiria: Dar al-Fikri, 1985.

[14]. www.pesantrenonline. 